\title{
ROGER, Scruton Vernon (2010). The Uses of Pessimism and the Danger of False Hope. Reino Unido: Atlantic Books. Traduzido por José António Freitas e Silva com a revisão de João Assis Gomes (2011). As Vantagens do Pessimismo, Lisboa: Quetzal Editores, pp. 230. ISBN: 978-972-564-927-5.
}

Roger Scruton, nascido em 1944, escritor, filósofo e comentador tem refletido sobre política e cultura no âmbito de uma vasta e constante colaboração com a imprensa. É professor catedrático e investigador no Instituto das Ciências Psicológicas em Washington DC e Oxford. Autor de vários livros desde 1974, vários romances, óperas, etc. Conhecido no Reino Unido como figura chave na "Nova Direita".

Roger Scruton, intelectual, polémico, pela visão conservadora do Mundo, o que o leva a ter muitos admiradores, mas também odiado por outros. Mesmo quando não se concorda pelas suas posições conservadoras e polémicas é desafiador e estimulante a sua leitura. Esta obra de Roger cujo original em inglês apareceu em 2010 e traduzido para português em 2011, escrito num período de profundas mudanças e crises no mundo e especialmente na Europa, atribui ao otimismo a raiz de todos os males. Esta sua posição continua a acentuar as controvérsias já observadas noutras obras que produziu. Aqui apresenta um conjunto de teses que se prestam a acesas discussões por causa do modo rígido como vê a evolução do mundo a nível cultural, político, económico e moral.

O livro, é demasiado atual nos tempos em que nos encontramos, manifesta como o pessimismo é útil em certos momentos em que os governantes com idealismos falsos prometem sempre novos mundos com efeitos sobre as pessoas, muitas vezes negativos, por vezes até destrutivos. O autor parte do princípio de que o uso do pessimismo apela à razão à liberdade e à responsabilidade para debelar as consequências do falso otimismo e dos enganos que derivam de estratégias da história do continente europeu como o fascismo, o nazismo e o comunismo.

Concorde-se ou não com as teses do autor e as opiniões estão longe de ser unânimes, o certo é que elas não nos podem deixar indiferentes.

A obra: As Vantagens do Pessimismo e o Perigo da Falsa Esperança encontra-se estruturada com um prefácio do autor e 12 capítulos assim intitulados: "O Futuro da Primeira Pessoa", "A Falácia da Melhor das Hipóteses", "A Falácia do Nascido Livre", "A Falácia Utópica", "A Falácia da Soma Zero", A Falácia do Planeamento", "A Falácia do Espírito em Movimento", "A Falácia da Agregação", "Defesa contra a Verdade", "O Nosso Passado Tribal", "O Nosso Presente Civil" e "O Nosso Futuro Humano". 
Foquemos então mais de perto alguns aspetos que merecem ser equacionados, discutidos ou até refutados.

$\mathrm{O}$ alvo de Roger Scruton é universal: "a esperança desligada da fé e sem ser mitigada pela evidência da História é uma coisa perigosa e o pessimismo informado é a arma mais eficaz contra a falsa esperança e as ilusões" (p. 9-10). A fé, a esperança e o amor são as virtudes que orientam a vida para o bem-estar maior.

Scruton ocupa-se essencialmente do progresso científico e do impacto que a História tem registado desde a invenção da roda, aos caminhos-deferro, sem que estes tenham perturbado e destruído a tranquilidade rural, desenraizaram as comunidades estabelecidas, puseram-nos a todos em movimento, quando o sentido da vida humana era ficarmos calmamente onde estamos. "...o pessimista moderno incita-nos a pensar no que nos acontece quando forem eliminadas as antigas restrições, abolidas as antigas limitações, e substituído um velho modo de confrontar o mundo por uma ilusão de domínio" (p.16). As máquinas estão sempre a melhorar, mas representam um perigo terrível. A máquina seguinte é sempre melhor, o processo de melhoramento continuará até que as máquinas já não precisam de seres humanos até serem capazes de se produzir e reproduzir. Assim, as máquinas travam uma luta com os seus concorrentes sendo que o seu único concorrente é o Homem. As relações, a tranquilidade, a confiança e o amor foram postos em perigo e continuam. $\mathrm{O}$ autor vê as decisões humanas como situadas, constrangidas pelo lugar, pelo tempo e pela comunidade, pelo costume, pela fé e pela lei. Incita-nos a não nos atirarmos sempre para a corrente das coisas, mas sim a ficarmos de lado e refletir. Recorda-nos a imperfeição humana e a fragilidade das comunidades reais. As suas decisões têm em conta outras pessoas e outros tempos. Para aqueles que dizem "avança" e "sempre em frente" é não te preocupes com o dia de amanhã" (p.26). Com isto o autor não sanciona um pessimismo global, mas a dose ocasional de pessimismo para moderar as esperanças que doutro modo poderiam arruinar-nos. "É a voz da sabedoria num mundo de ruído. E exactamente por esta razão, ninguém a ouve".

Para Scruton a presente crise do Mundo em geral e da Europa em particular, deve-se a erros sucessivos e estratégias mal conseguidas e programadas de tal forma graves que colocam o mundo numa instabilidade económica, financeira e política. $\mathrm{O}$ excesso de confiança de quem governa o mundo conduziu a especulações, a um otimismo cego que nos conduziu à atual situação. As coisas descontrolam quando os modos falaciosos de raciocinar se imiscuem na política (p.39).

É fundamental adquirir uma imagem mais completa dos recursos intelectuais a que as pessoas podem recorrer ao reorganizarem a realidade para se ajustar à forma das suas esperanças e evitar a difícil tarefa a que a razão as chama, que é reorganizarem as suas esperanças para que se 
ajustem à forma da realidade e ultrapassar algumas falácias ligadas ao otimismo mas destituídas de realismo (p.81 e ss.).

Scruton está convencido de que a autoilusão encerra mais danos do que benefícios. Encontramos esta sua convicção em todos os capítulos do livro. Crítica de modo desassombrado e muito áspero os burocratas de Bruxelas, mas também os pedagogos que desvirtuaram a educação, ao decidirem que a mesma não tinha que ver com a obediência e estudo mas com a autoexpressão e recreação. Ao longo de toda a obra salta à vista o resultado da entrega dos nossos destinos coletivos a incompetentes. Mas crítica de modo violento os regimes políticos, a imigração descontrolada e o fundamentalismo islâmico.

As sociedades entraram num período de instabilidade e ameaça. Foram conduzidas a este ponto por maneiras de pensar que são irracionais (p.162). Um exemplo dessa estratégia foi o incentivo irracional e desmedido ao consumo. Numa economia de crédito, em que as pessoas procuram desfrutar agora e pagar depois, a responsabilidade está constantemente a diminuir (passim). Podemos proteger-nos das falsas esperanças e adquirir verdadeiras esperanças através de três estratégias: Defesas contra a verdade. Esta defesa é habitualmente usada em ações defensivas que mostram o modo como os seres humanos conspiram para evitar a verdade, sempre que a verdade exige uma mudança de rotinas. Falsas perícias, inventadas, têm sido úteis para sustentar falsas esperanças. A culpa transferida: quando acontecem coisas más, procuramos a pessoa, o grupo ou o coletivo que as causou e a quem possa ser atribuída a culpa. A terceira estratégia para evitar a verdade, o hermetismo tem tido grande impacto nas universidades e envolve não defender a posição de uma pessoa mas sim escondê-la para proteger as suas ilusões. A criação de bodes expiatórios: em momentos de tensão, quando as ilusões do otimista estão em perigo de refutação, o crítico é transformado em inimigo interno, não é ele que está a argumentar a favor de uma posição rival, é ele que se destaca da multidão como vítima sacrificial, é ele o bode expiatório (p.167-178). Estas estratégias mostram hábitos defensivos que se mantêm entre nós. Hábitos que servem para desviar as nossas decisões coletivas do ceticismo razoável que é necessário e para colocar no lugar dele falsa esperança. Não são só os otimistas que se entregam a esses hábitos, para Scruton "sempre que foi construído um modo de vida com base numa crença falsa ou questionável, as defesas vêm em socorro dos crentes"(p.188). "Nenhum paraíso parece tão ao abrigo de tempestades intelectuais como o paraíso das falsas esperanças” (p.189), E contínua: “...em vez de nos perdermos nessas esperanças irrealistas, devemos reflectir outra vez sobre a nossa natureza de criaturas estabelecidas e que negoceiam, e voltar à nossa missão, que é olhar com ironia e desprendimento para a nossa real 
situação e estudar a maneira de viver em paz com aquilo que encontramos" (p.223).

Portanto, Scruton tem uma visão conservadora e rígida do mundo o que põe em confronto aqueles que o admiram com aqueles que o detestam. Na sua argumentação defende a ideia de que o maior perigo e a maior ameaça advieram sempre dos que defenderam o idealismo e o otimismo, fossem da direita ou da esquerda. É preciso substituir este irracionalismo pelo pessimismo humano, porque o otimismo é a raiz de todos os males.

Maria Olívia Dias 